\title{
Marek Hendrykowski \\ Strzał z dystansu. O Pierwszej piątce Stanisława Barańczaka
}

\begin{abstract}
Hendrykowski Marek, Strzał z dystansu. O „Pierwszej piątce” Stanisława Barańczaka [A shot from a distance. On Pierwsza piątka (The First Five) by Stanisław Barańczak]. „Przestrzenie Teorii" 26. Poznań 2016, Adam Mickiewicz University Press, pp. 207-219. ISSN 1644-6763. DOI 10.14746/pt.2016.26.14.

Marek Hendrykowski's article provides an analysis and interpretation of Barańczak's well-known poem "Pierwsza piątka" [The First Five], whose main characters are the basketball legends of Boston Celtics, NBA champions on many occasions.
\end{abstract}

Kto nie interesuje się sportem, nie wejdzie do Królestwa Niebieskiego.

ks. Kazimierz Zachman proboszcz z Gozdowa

\section{Wielcy poeci pod koszem}

Wielcy poeci z zasady nie piszą o koszykówce. To kultura masowa, rozrywka tłumów i opium dla kibicujących rozgrywkom mas. Rzecz z natury niepoważna - coś błahego, co mogłoby podawać w wątpliwość i podważać poetycką „wielkość” autora. Dlatego wszyscy „wielcy” poeci raczej $\mathrm{z}$ daleka omijają podobne tematy. Wiersze poświęcone koszykówce są rzadkością. Jeśli już, to piszą je nie ci „wielcy”, lecz jedynie najwięksi, najbardziej wybitni poeci. Do tego jeszcze ta prozaiczna zespołowa gra i bieganina między dwoma koszami. Gdzie tu poezja? Decathlon, bieg maratoński, rzut dyskiem, sięgająca antycznych mitów rywalizacja gigantów... Owszem, to uchodzi za temat godny pióra poety.

Dawno już zatarło się w zbiorowej pamięci, iż pisanie wierszy o sporcie bywało w nieodległej przeszłości zaszczytną konkurencją artystyczną premiowaną laurami i medalami (Kazimierz Wierzyński zdobył złoty medal w konkursie literackim IX Igrzysk Olimpijskich w Amsterdamie, 1928, za tom poetycki Laur olimpijski). O sporcie można ułożyć wiersz, poemat czy tom wierszy. O sporcie tak - w klasycznej wystylizowanej formie, z właściwym namaszczeniem i podejściem do tematu, ale nie o meczu zawodowej amerykańskiej koszykówki. To po prostu nie wypada... 


\section{Pierwsza piątka}

W oceanicznym ryku nabitej głowami hali

Boston Garden, w ekstazie od górnych galerii po parter, wbiegają truchtem, luźni, zblazowani, cali

W niby-leniwej glorii, pięć piętrowych panter:

Długoręki Kevin McHale, sześć stóp i dziesięć cali

ofensywnego geniuszu; chmurny i uparty

wielkolud Robert Parish; piegowaty Dennis

Johnson, mistrz błyskotliwych podań; jego partner

Danny Ainge, cwany gówniarz z wyglądu, bezcenny

artysta strzałów z dystansu; aż wreszcie wstępuje na parkiet

Larry Bird (z trybun: „LA-RREE!!!”), kluchowaty, senny

blondas, w którym nikt by się nie domyślił żywej,

jedynej, wszystko dotąd zaćmiewającej legendy.

Fale wrzawy wzbierają, aż burzliwe grzywy

walą się, nagła cisza święci ewidentny

fakt: w dziejach koszykówki nie było dotąd drużyny tak zgranej, niezrównanej. Gwizdek, pierwszy wyskok do piłki. Parish; Johnson; McHale czterema dużymi krokami dopada kosza, dwa punkty, ryk: znów im wyszło. „Socjotechnika: bez meczów, lig, tabel zbyt by się dłużyły

tygodnie", mruczę zawistnie. (Bird rzuca się w kłębowisko ciał, zwód, łuk strzału: znowu!). Nie: tylko trochę mniej niedoskonali niż każdy, są doskonale kochani, nienawidzeni, są wyspą wyrosłą nad obojętność. Na mgnienie. Tak, ale na mgnienie ocali ich to, że wystają o głowę ponad tę resztę, to wszystko.

\section{Poeta jako kibic}

Kto nie znał Stanisława Barańczaka, kto się z nim osobiście nie zetknął, ten nie wie, jak wybornym był kibicem. Sportów żadnych od dzieciństwa z zasady nie uprawiał. Za to się sportem pasjonował, żył nim, namiętnie chłonął jego uroki, potrafił o tym rozmawiać godzinami. Kiedy po kilku latach niewidzenia zobaczyliśmy się znów z Anią i Staszkiem w ich domu w Newtonville na przedmieściach Bostonu, jednym z pierwszych amerykańskich tematów w naszej rozmowie stała się ni stąd ni zowąd legendarna drużyna Boston Celtics. Temat ruszył sam gospodarz. 
Nie zdziwiło mnie to ani trochę: właśnie dlatego, że chodziło nie o baseball, boks zawodowy, futbol amerykański, ale o rozgrywki ligi basketu.

W pierwszej połowie lat sześćdziesiątych Stanisław był uczniem i absolwentem poznańskiego „Marcinka” (I Liceum Ogólnokształcące im. Karola Marcinkowskiego), w którym koszykówka cieszyła się szczególnym prestiżem. Wiktor Haglauer, jeden z nauczycieli wychowania fizycznego, uczynił grę w kosza grą $\mathrm{w}$ tej szkole kultową, formując licealną drużynę złożoną z utalentowanych dryblasów, z których niejeden zasilił później szeregi pierwszoligowego Kolejarza bądź też grał „u konkurencji” w klubie AZS Poznań. O koszykówce na okrągło się w szkole rozmawiało.

Haglauer był za młodu graczem pierwszej piątki poznańskich „lokomotyw". W 1958 roku sięgnął z kolegami po mistrzostwo Polski. Po ukończeniu studiów na Akademii Wychowania Fizycznego przez trzydzieści lat prowadził i trenował tę drużynę, wielokrotnie zdobywając $\mathrm{z}$ nią mistrzostwo i wicemistrzostwo kraju. Nic dziwnego, że jedną z pierwszych rzeczy, jakie musiał opanować każdy uczeń I Liceum (było ono jeszcze wtedy męskie), stanowił zakończony celnym strzałem za dwa punkty koszykarski dwutakt, który zdawało się na ocenę.

Warto w tym miejscu dodać, iż zapomnianym dzisiaj wydarzeniem tamtych czasów stała się w Poznaniu jednodniowa wizyta słynnej zawodowej amerykańskiej drużyny koszykarskiej. Oficjalnie zespół nosił nazwę Harlem Globetrotters, jednak wszędzie mówiono na nich z podziwem Czarne Błyskawice. Podczas tournée po Europie koszykarze z Nowego Jorku przyjechali na moment właśnie do Poznania, gdzie rozegrali przetykany niezliczonymi sztuczkami z piłką popisowy mecz na Stadionie Warty w obecności tłumu zachwyconych widzów.

Dodam jeszcze, iż latem roku 1960 wszedł też na ekrany polskich kin amerykański film pod tytułem Czarne błyskawice (reż. Phil Brown, 1951). Obraz dość marny, ale za to naszpikowany cyrkowymi popisami i trikami czarnoskórych graczy. Staszek zetknął się więc z kultową aurą tej gry jeszcze w „Marcinku”; jednak pokochał koszykówkę miłością namiętną i gorącą dopiero w Bostonie, po przyjeździe na Harvard, odkrywając „u siebie” już nie cyrkowy, lecz ligowy najlepszy zespół koszykarski świata.

\section{Koszykówka jako poezja}

Na pierwszy rzut oka, czegoś takiego jak gra w koszykówkę wydaje się nie łączyć z poezją nic, dosłownie nic. Z pozoru sądząc, rzeczywiście nic, ale to tylko pozór. Pierwsza piątka Stanisława Barańczaka dowodzi, 
że w istocie obie sfery - poezję i basket - łączy z sobą bardzo wiele. Rzec można, iż słuch absolutny poety połączył się w tym kapitalnym wierszu $\mathrm{w}$ jedno ze słuchem absolutnym kibica sportowego. Strona referencyjna tego utworu - skądinąd ważna, bo zawierająca w sobie uwiecznioną w kilku strofach pamięć najlepszej drużyny koszykarskiej wszech czasów - została wyposażona przez autora w niezmiernie kunsztowny kształt poetycki.

Jest rzeczą doprawdy fascynującą obserwować, jak pod piórem Barańczaka koszykówka, prawda, że w wykonaniu Celtów, przybiera dojrzałą formę literacką, awansując do rangi tematu poetyckiego. Tytuł Pierwsza piątka wydaje się zaczerpnięty z nagłówka jakiejś gazety o tematyce sportowej czy magazynu poświęconego basketowi. Zabieg z tytułem sam w sobie oczywisty i niewymagający dodatkowych objaśnień. Tyle że na tym nie koniec, bowiem poeta okazuje się o wiele bardziej otwarty na jego poetyckie rozpisanie, na różne sposoby rozwijając wyjściowy koncept liczby pięć w architektonice całego wiersza. Nie dość, że konstrukcja utworu liczy sobie ni mniej ni więcej tylko pięć zwrotek, to jeszcze każda $\mathrm{z}$ nich zawiera bardzo nietypową, rzadką w poezji polskiej, liczbę pięciu wersów w strofie.

Spodziewałby się może kto, iż zgodnie z narzucającą się logiką każda $\mathrm{z}$ następnych strof Pierwszej piątki będzie poświęcona z osobna jednemu z pięciu słynnych graczy. W pierwszej więc, dajmy na to, Parish, w trzeciej McHale, a w ostatniej Bird? Ależ skąd! Barańczak ani myśli narzucać całości wiersza tak mechaniczny - a przez to banalny - porządek rozwoju. Portretuje bostońskich Celtów całkiem inaczej. Od pierwszej do ostatniej chwili konsekwentnie spogląda na nich jako na drużynę, zachwycając się jednością, jaką wspólnie tworzą. I tak samo konsekwentnie jako dream team „traktuje” ich w swoim wierszu.

Przekonuje o tym wypróbowana broń poetów: interpunkcja. W Pierwszej piatce przypada jej do spełnienia eksponowana rola regulatora strategii gry, w której stawką jest obraz wielkiej koszykówki. Nie jest dziełem przypadku, iż tak wiele razy, bo aż sześciokrotnie, pojawiłby się w użyciu średnik. Po co? Dlaczego właśnie on? Zauważmy tylko, gdzie się pojawia: jest tam, gdzie pojawiają się nazwiska i charakterystyki koszykarzy. Funkcjonuje niczym spoina. Wyznacza przestrzeń między nimi. Głęboko przemyślaną poetycką funkcją i zadaniem średnika okazuje się równocześnie: oddzielać i łączyć piątkę graczy. Dzięki temu każdy z nich zachowuje w utworze własną inność, osobność i imienną indywidualność, a jednocześnie grają razem, biegną pod kosz i są nieopodal, czują nawzajem swoją obecność, podają sobie piłkę, wychodzą na pozycje i wygrywają 
wielki mecz na boisku tego wiersza. Tak oto umiejętnie użyty średnik staje się, paradoksalnie, naraz działem i złączem poetyckiej frazy.

O ile Pierwsza piatka dba o układ strof, o tyle generalnie nie trzyma reguł międzywersowego izosylabizmu. W pierwszej strofce rozbieżność w liczbie sylab jednego wersu waha się między 13 a 16! Żywioł gry mowy toczącej się w tym utworze momentami wydaje się dosłownie wylewać poza linię autową poetyckiego boiska (sytuacja typowa dla basketu), by po chwili powrócić do jakiej takiej chwiejnej regularności. Podobnie jak w strofie inicjalnej wygląda owa intrygująca rozpiętość w następnych zwrotkach: w drugiej mamy przedział 13 do 17 zgłosek, w trzeciej - nieco skromniejszy 13 do 15, w czwartej znów 13 do 17, a w ostatniej wyjątkowe szaleństwo poetyckiej swobody - 16 do 20 sylab!

Autor Pierwszej piątki najwyraźniej skwapliwie unikał i po prostu nie chciał starannie wypracowanego, wzorcowo odrobionego i stricte odliczonego regularnego sylabowca. Coś podobnego stanowczo nie było po jego myśli. Dlatego też na przestrzeni jego utworu jako całości skala zróżnicowania długości poszczególnych wersów przybiera ostentacyjną wyrazistość, wynosząc od 13 do 20 sylab. W sumie zakrawałoby to na elementarną warsztatową nieumiejętność, gdyby nie było zamierzone i celowe.

Nie chodzi przy tym o żadną banalną peryfrazę czy metonimię będącą wytworem powierzchownie pojętej „poetyczności”, która miałaby nazwać i w dosłowny sposób odwzorować naturalną arytmię, migotliwość i błyskawiczną zmienność gry w koszykówkę. Stawka, po którą sięga poeta, okazuje się nieporównanie większa, chodzi o ryzykowną przenośnię poetycką tej kunsztownej i złożonej gry. Metaforę niesioną autorskim podziwem dla jej maestrii osiągniętej w takim jak to, genialnym wydaniu Birda i kolegów. Wiersz ma, o ile możliwe, sprostać temu wyzwaniu, stawić mu czoła dzięki magii innego kunsztu: mowy wiązanej.

Co uderza czytelnika w tym wierszu najbardziej? - Metafizyka sportu. Oglądając wspólnie ze Staszkiem w poznańskim mieszkaniu Barańczaków przy ulicy Kościuszki transmisje telewizyjne wielkich wydarzeń sportowych, wielokrotnie miałem okazję obserwować jego niezwykły dar wyławiania rzeczy wyjątkowych, jedynych w swoim rodzaju. Takich, które nie powinny się zdarzyć, a jednak - za sprawą czyjegoś nadludzkiego wysiłku, ale także przy udziale łaskawej fortuny - się wydarzyły: na bieżni, na skoczni (pamiętne osłupienie sędziów po rekordowym skoku Boba Beamona na olimpiadzie w Meksyku), na torze, na parkiecie, na boisku. Kibic sportowy Barańczak polował na takie zdarzenia i potrafił się nimi delektować i cieszyć jak dziecko. 
W wierszu Pierwsza piątka nieprzypadkowo pojawia się słowo ekstaza (z gr. ékstasis - 'wyjść poza siebie', 'przekroczyć granice', także stan zachwytu, uniesienia; ekstatikós - 'ruszony z miejsca'). Ciekawe, że właśnie uczucie zbiorowej ekstazy łączy w tym utworze podmiot liryczny, widownię i graczy. Autor poszukuje optymalnie nośnego sposobu, dzięki któremu sztuka poetycka wyjdzie na spotkanie kunsztowi i żywiołowej radości przeżywania uprawianej na takim poziomie koszykówki. Zmienne tempo i rytm tej gry, zdawać by się mogło nie do uchwycenia w słowach, stanowią dla niego największe wyzwanie i trudność, domagając się odkrycia i wykreowania poetyckiego ekwiwalentu.

Nikomu wcześniej nie udało się opisać za pomocą mowy wiązanej pulsującego tętna i sensualnej urody zawrotnej zmienności koszykarskich akcji. To magia, dla której ogląda się mecz za meczem, czekając na jeszcze więcej niż działo się na parkiecie poprzednio. Barańczak kibic basketu, niczym gracz nagle obdarowany piłką pod koszem, próbuje ów dar przekazać i oddać to uczucie - i w końcu znajduje właściwą drogę. Nie tylko poezja, także sam basket jako pasja ma w sobie coś głęboko osobistego. Nawet rzut wolny wykonywany pod tablicą zwany jest w polskiej koszykówce rzutem osobistym, bo wykonuje się go w pojedynkę.

Powtórzmy: wielka poezja i wielka koszykówka wcale nie są od siebie daleko. I tu, i tam mamy do czynienia z ciągłym napięciem dyscypliny i spontaniczności podejmowanych działań (tempo, rytm akcji, liczba kroków, konieczność kozłowania, dwutakt pod koszem, liczba wersów, ich wewnętrzna struktura, układ rymów, delimitacja fragmentów pola, logika rozwoju gry, uważność wszelkich zachowań i kolejnych poczynań, przeszkody po drodze, opór materii, zaskakujący przerzut w polu gry i równie zaskakująca przerzutnia w wierszu itd.). Dwie gry, dwie formy ludzkiego kunsztu, dwie zbliżone do siebie analogiczne umiejętności, dwie maestrie. Trafia się piłką rzuconą do kosza bądź trafia celnym słowem dokładnie w punkt. Sporo tego, ale z pewnością nie wszystko.

Pierwszorzędnie ważnym wyznacznikiem obu tych dziedzin jest wiązanie elementów i składność ich połączenia odkrywana w nieustannej przemianie i dynamice przemyślnie zorganizowanego ruchu występującego w wierszu i na parkiecie. Składność okazuje się nieodzowna w każdej: zarówno poetyckiej, jak i koszykarskiej akcji. Nieprzypadkowo jeden z rzadziej dzisiaj używanych $\mathrm{w}$ języku potocznym synonimów drużyny i teamu stanowi słowo skład. Skład niczym składnia. Składa się wiersze, składa się zespół. To właściwie dobrany skład tych a nie innych graczy tworzy znakomitą drużynę; to również idealnie trafiony i skomponowany skład wielkich osobowości przemienia zespół w dream team. 
Sięgnijmy po strukturę rymów tego wiersza. Ich doskonale zaprojektowany układ opiera się na czytelnym schemacie A-B-A-B-A, C-D-C-D-C itd. W pierwszej zwrotce: hali - parter - cali - partner - cali, w drugiej bez porównania odleglejsze skojarzenia dźwiękowe: uparty - Dennis partner - bezcenny - parkiet. W trzeciej podobnie: senny - żywej - legendy - grzywy - ewidentny. W czwartej: drużyny - wyskok - dużymi wyszło - dłużyły. I w ostatniej piątej - dochodzi do głosu najpiękniejsza ze stworzonych w tym utworze poetyckich konfiguracji: kłębowisko - niedoskonali - wyspą - ocali - wszystko. To rymotwórczy majstersztyk Barańczaka unikający mechaniki rymowego banału: co rusz zaskakujący słuchacza kunsztownymi asonansami i konsonansami.

Aranżując nieoczekiwane zbieżności, szukając kolejnych miejsc wspólnych i kreśląc trajektorię stycznej, autor Pierwszej piątki postawił nie tylko na rym (mamy tu bowiem wiersz o rymach bardzo finezyjnych, uchylających oczekiwane proste współbrzmienia), lecz również na inne możliwości. Nieobecność regularnych rymów nietrudno wytłumaczyć. Stanowiłyby one kłopotliwy balast i sztucznie podtrzymywany nadmiar, psując aleatorykę wiersza i absolutną nieprzewidywalność opisywanych w nim sytuacji na koszykarskim boisku. Najważniejszym z poetyckich sposobów okazuje się tu jednak nie rym i nie starannie wypracowany w każdej linijce monotonnie równy sylabowiec, lecz co innego: rewelacyjnie wykorzystana przez Barańczaka funkcja średniówki i przerzutni.

Przy tak długich wersach (od trzynastu do aż dwudziestu sylab w linijce) średniówka trzyma w ryzach i spina łamliwą całostkę. Większość średniówek przypada tutaj po siódmej, część z nich zachodzi nieco dalej: po ósmej. W przeciwieństwie do spinającej więźbę utworu funkcji średniówki, przerzutnia szeroko rozpościera konstrukcję wiersza, nadając jej dynamikę i rozmach. Autor Pierwszej piątki stosuje ją nieustannie. Nie tylko pomiędzy poszczególnymi wersami, ale także o wiele bardziej śmiało i ryzykownie: między strofami, co jest poetyckim ewenementem.

Umiejętność - kunszt - codzienne ćwiczenie - życie połączone z osobistą pasją: do gry w koszykówkę czy też do pisania wierszy, wszystko jedno. Dokonać czegoś niezwykłego, nieprawdopodobnego, czego dotąd nie dokonał nikt: sięgnąć granic ludzkiej niemożności, dotknąć nieosiągalnych wcześniej dla nikogo możliwości, przetestować ich istnienie, poczuć naturalny opór i spróbować przekroczyć tę granicę. Uprawiana na takim poziomie autorskiej maestrii poezja okazuje się $\mathrm{w}$ tej sferze niezmiernie bliska sportowi i vice versa.

Jednym z najbardziej nieprawdopodobnych wyczynów koszykarskich Birda zanotowanych w kronikach NBA stał się moment jego upadku 
z piłką $\mathrm{w}$ otoczeniu kilku obrońców drużyny przeciwnej. Kiedy w krytycznym momencie podjętego ataku już-już wydawało się, że mierzący $206 \mathrm{~cm}$ stukilogramowy olbrzym musi nieodwołalnie runąć na ziemię i nieuchronnie upaść na parkiet w polu zwanym „trumną”, lider Boston Celtics zdołał mimo wszystko utrzymać równowagę i nadludzkim wysiłkiem - między lasem rąk - wpakował trzymaną przez siebie oburącz piłkę prosto na tablicę, strzelając zaskoczonym rywalom dwa punkty. Niemal cudem oddalona przez gracza klęska indywidualnej szarży na kosz zamieniła się nagle w triumf. Takie niezapomniane chwile i zdarzenia, kiedy ich naocznym świadkiem staje się poeta, okazują się warte uwiecznienia wierszem.

\section{Legenda Celtów}

Boston Celtics nie są zwykłym klubem koszykarskim, jakich wiele. Są legendą zawodowej ligi NBA (National Basketball Association). W historii jej rozgrywek aż siedemnaści razy (!) sięgali po mistrzostwo Stanów Zjednoczonych. Emigrant zza Wielkiej Wody, profesor Uniwersytetu Harvarda Stanisław Barańczak sezon w sezon był świadkiem, jak w dekadzie lat osiemdziesiątych Wielcy Celtowie osiągali niebotyczne szczyty koszykarskiego kunsztu. Mogli w tamtym czasie wygrać z każdą drużyną świata i wygrywali. Arnold Jacob „Red” Auerbach długo i wytrwale kompletował Wielką Piątkę, przez kilka lat pozyskując do niej kolejnych graczy: Birda, McHale'a, Parisha, Johnsona i Danny'ego Ainge'a.

Ilekroć czytam ten kapitalny wiersz, uderza mnie jego rozemocjonowany podmiot $\mathrm{w}$ roli zafascynowanego swoją drużyną miłośnika tej pięknej gry. Kim jest? Przede wszystkim poetą w roli kibica i vice versa - kibicem, który podziwia jej kunszt okiem poety. Jaka przypada mu rola? Może być szefem klubu albo obdarzonym fenomenalną intuicją selekcjonerem, który po paroletnich niestrudzonych wysiłkach i serii zakupów będących rezultatem finezyjnych draftów właśnie skompletował piątkę marzeń, albo ich coachem, albo po prostu zachwyconym widzem - fanem wielkiego zespołu gwiazd. Bo też był to zespół legendarny.

$\mathrm{Z}$ osobna wzięci Boston Celtics niekoniecznie zajmowali pierwsze miejsca $\mathrm{w}$ niezliczonych rankingach $\mathrm{NBA}^{1}$. Poszczególni gracze plasowali się w nich bardzo wysoko i grali w prestiżowych meczach All Stars (zmaganiach najlepszych w danym sezonie rozgrywek NBA reprezentantów

1 W latach 1986-1987 Larry Bird sięgnął po prymat NBA w rankingu rzutów z dystansu. 
drużyn Wschodniego i Zachodniego Wybrzeża), ale Johnson, Ainge, $\mathrm{McHale}$, Bird i Parish nie pretendowali z tego tytułu do miana wielkich indywidualności i do statusu gwiazd zawodowej koszykówki. Ich klubowe, a nie ligowe gwiazdorstwo wyrażało się bez porównania skromniej tym, że wnosząc tyle do gry i poziomu swojej drużyny, otrzymali przywilej stałych numerów na, opatrzonej klubowym logo Celtów Ceprechaun, biało-zielonej koszulce: OO C (Parish), 3G (Johnson), 32 F (McHale), 33 F (Bird), 22 (Ainge).

Stanisław Barańczak dostrzega i na każdym kroku podkreśla w swoim wierszu, że jego ulubieni gracze - wykorzystując swój naturalny talent, wrodzoną dyspozycję i dając drużynie niezbędną dla jej wielkości cząstkę w postaci opanowanego przez siebie kunsztu, a przy tym zachowując niepowtarzalną wyrazistą osobowość - stanowią Wielką Piątkę. To wiersz o synergii. O wspólnocie twórczego dążenia, która jest czymś nieporównanie wspanialszym od zwykłej sumy talentów tych pięciu. Nieistotne były ich takie czy inne indywidualne koszykarskie osiągnięcia. Tworząc przez dekadę dream team Boston Celtics, ci pościągani z różnych stanów Ameryki (Indiana, Oregon, Teksas, Luizjana, Minnesota) zawodnicy liczyli się razem jako drużyna wszech czasów. Tak właśnie widzi ich i z zachwytem opisuje poeta.

\section{Bird}

Pochodzący z Indiany Larry Bird zadebiutował w Celtach jako 23-latek w roku 1979. Nie od razu wszedł w rolę lidera zespołu. Przez pierwszy sezon ciężko pracował na swą pozycję, z meczu na mecz udowadniając Arnoldowi „Redowi” Auerbachowi, że zasługuje na większe zaufanie niż to, które na początek od niego otrzymał. Legendarny trener koszykarzy Boston Celtics potrzebował kogoś, kto poprowadzi grę zespołu, a podejmując kluczową decyzję o angażu, widział w nim jedynie wysokiej klasy skrzydłowego. Dopiero z czasem miało się okazać, iż Larry jest urodzonym, fenomenalnie uzdolnionym playmakerem i niekwestionowanym liderem drużyny, która w następnym sezonie rozgrywek stopniowo przezwyciężając głęboki kryzys, pięła się z podrzędnego dotąd miejsca w górę tabeli NBA.

Bird był doskonałym taktykiem i strategiem, potrafił fenomenalnie „czytać grę": zarówno swoich partnerów, jak intencje przeciwników. Miał też wrodzony talent przywódczy. W krytycznym momencie meczu, gdy ważyły się jego losy, a widmo przegranej zaglądało własnej drużynie 


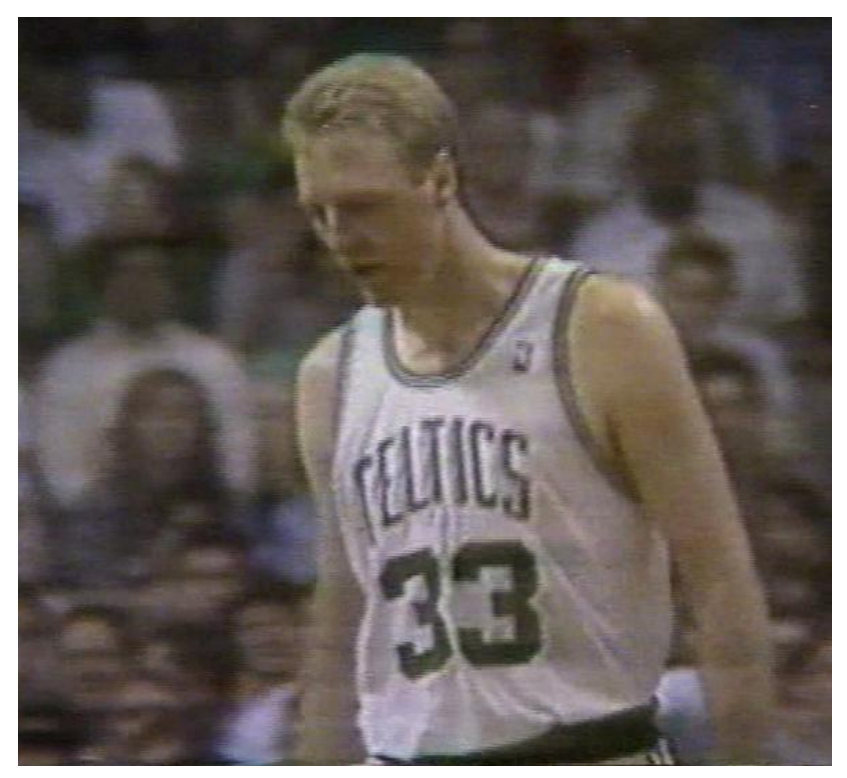

w oczy, potrafił poderwać kolegów do boju i - na oczach zdumionej widowni - odwrócić niekorzystną sytuację na parkiecie. „Kluchowaty” i „senny”, jak pisze Barańczak, podczas gry o najwyższą stawkę zachowywał pokerową twarz, spokój, zimną krew i całkowite opanowanie: zadając rywalom ostateczny cios w momencie, kiedy najmniej się spodziewali. Absolutny fenomen rzutów z dystansu za trzy punkty, triumfator licznych konkursów w tej specjalności koszykarskiej.

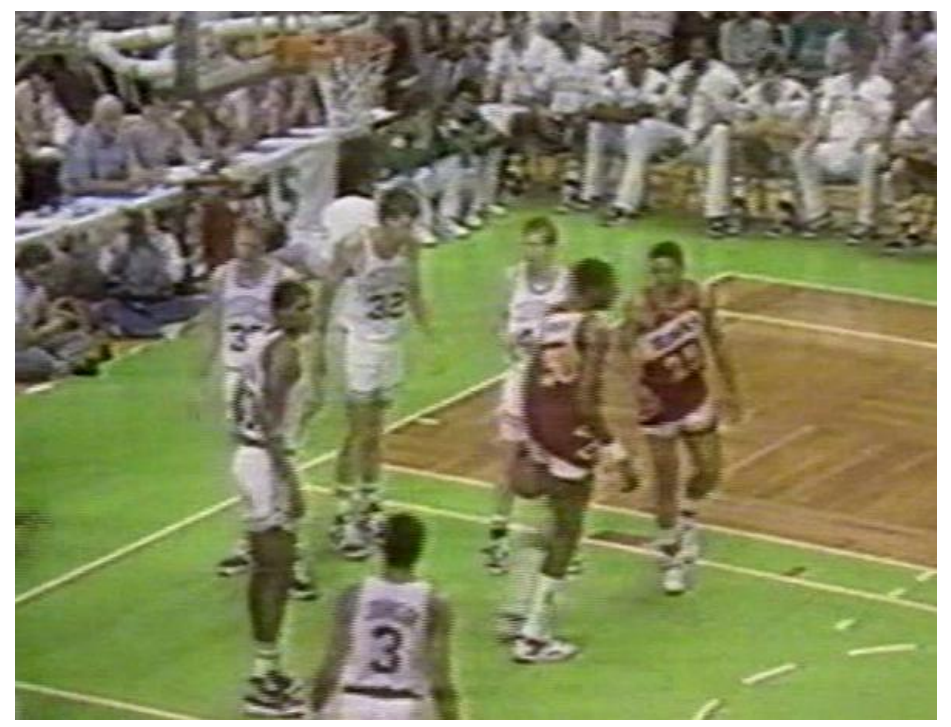




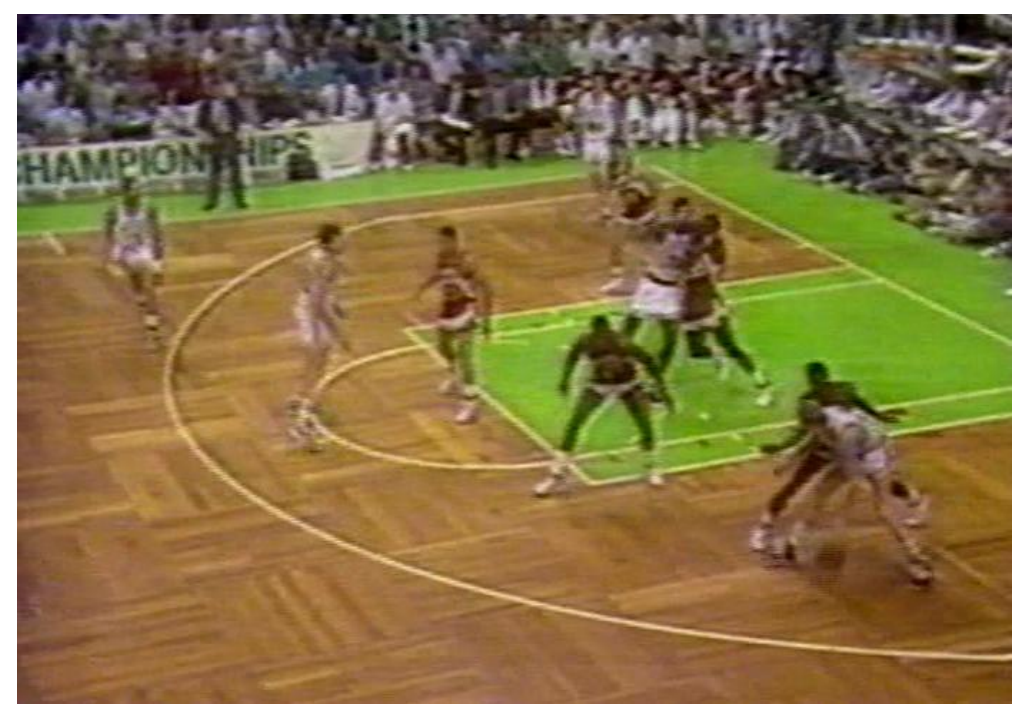

Porównywano go do dwójki legendarnych poprzedników: Billa Russella i White'a Chamberlaina. W czasach, kiedy występował, konkurencja wśród liderów najlepszych drużyn NBA była niezwykle wyśrubowana. Wystarczy sobie uświadomić, że do elitarnego grona jego konkurentów zaliczali się legendarni już wtedy zawodnicy: Michael Jordan (Chicago Bulls), Magic Johnson (rozgrywający „Czarodziej” Los Angeles Lakers), Dominique Wilkins, Isiah Thomas, Kareem Abdul-Jabbar oraz Clyde the Glide (Clyde Szybowiec), czyli Clyde Drexler z Portland Blazers. A jednak to on, Larry Bird, serce i mózg drużyny Celtów cieszył się w amerykańskiej lidze zawodowej koszykówki szczególną estymą i mianem „najlepszego białego w grze wymyślonej dla czarnych".

Bird to idol nr 1 kibica Barańczaka - swoista kwintesencja Wielkiej Piątki. Jako mistrz basketu był koszykarzem kompletnym: atak, defensywa, pressing, gra pozycyjna, nagłe uwalnianie się od obrońców w sytuacji podkoszowej (w takich momentach słychać było frenetyczny okrzyk sprawozdawcy: „Bird comes free!!!”). Każdą z tych umiejętności miał $\mathrm{w}$ małym palcu. Widownię wprawiały w zachwyt jego: zbiórki, asysty, natchnione crossowe podania („przerzutnie”) przez całe boisko, które w mgnieniu oka odmieniają przebieg gry, rzuty, czapy, smecze, haki, wsady i przechwyty. Potrafił dosłownie wszystko, zawsze tam, gdzie należało i we właściwym momencie. Występując na pozycji nazywanej fachowo small forward i power forward, grał na całym boisku, siał zamieszanie w szeregach przeciwnika i wszędzie można się go było spodziewać. 


\section{Studium przedmiotu}

W przypadku innego poety uwiecznianie przy użyciu mowy wiązanej wizerunków znakomitych sportowców i dokonanego przez nich niezwykłego wyczynu sportowego, mogłoby przybrać skądinąd dobrze przecież znaną formę: konwencjonalnej rymowanki, słów okolicznościowej piosenki, hymnu na cześć itp. W przypadku innego poety zapewne tak, ale mówimy tu o Stanisławie Barańczaku. Wielka Piątka Boston Celtics jako zaskakujący przedmiot jego omijającej wszelki banał wyobraźni poetyckiej nie mieści się żadną miarą w paru rymowanych strofkach ani w zwyczajnym metrum, dajmy na to, jedenasto- lub trzynastozgłoskowca. A może do opisu tak epickich czynów i wyczynów nadawałaby się lepiej stylizacja na heksametr? - Nic z tych rzeczy, nie o to bowiem chodzi.

To nie jest statyczny grupowy portret piątki graczy upozowanych na parkiecie do klubowej fotografii. Przedmiotem tego wiersza okazuje się basket: gra w koszykówkę doprowadzona do absolutnej maestrii przez drużynę jej mistrzów z Bostonu. Jak oddać dynamikę i żywiołową zmienność koszykarskich zmagań? Jak przekazać finezję wyszukanych akcji i błyskawicznych zagrań. Czy to w ogóle możliwe za pomocą słów, a tym bardziej w rygorach utworu poetyckiego? Wydaje się, że po prostu nie sposób czegoś takiego dokonać. Zwłaszcza, gdy zauroczony mistrzowską grą ulubionych koszykarzy kibic i fan $\mathrm{w}$ roli poety dodatkowo utrudnia sobie zadanie, starając się oddać rzecz nie prozą, lecz kunsztownym wierszem.

Autor Pierwszej piątki myśli kinematograficznie. Mając do swej dyspozycji czasoprzestrzeń wiersza, próbuje oddać naturę podziwianej gry za pomocą słów. Nie są one specjalnie wyszukane, raczej dość zwyczajne: część zaczerpnięta z języka potocznego, część z języka sprawozdawców sportowych relacjonujących na żywo to, co właśnie dzieje się $\mathrm{w}$ hali Boston Garden. Uderza plastyczność języka opisu akcji. „Bird rzuca się w kłębowisko ciał, zwód, łuk strzału: znowu!”. Naturalny talent koszykarza pozwala mu surfować na fali oceanicznych emocji widowni rozciągającej się „od górnych galerii po parter”. Kwintesencję podziwianej przez siebie drużyny poeta zawiera $\mathrm{w}$ jedności kunsztownej trzywyrazowej aliteracji: „pięć piętrowych panter”.

Geniusz poezji Barańczaka nie znał granic, obejmując swym zasięgiem nie tylko kapitalne tłumaczenia angielskich poetów metafizycznych, lecz również karkołomny dla kogoś mniej zdolnego niż on opis drużyny koszykarzy. Settembrini kibiców. Zawsze pełen nadziei na nowe wydarzenia, zawsze gotów obejrzeć i przeżyć coś niezwykłego. Reagował wówczas żywiołowo: całym sobą. $\mathrm{Z}$ pełnym zachwytu podziwem i niedowie- 
rzaniem. Autor Pierwszej piątki bardzo lubił wielki sport i równie chętnie kosztował przyjemności życia codziennego. Pasjonujący mecz na boisku czy parkiecie był dla niego czymś na podobieństwo smaku doskonale zaparzonej herbaty, łyka ginu z tonikiem albo cienko pokrojonego łososia.

Telewizor w Newtonville stawał się podczas rozgrywek ligi NBA meta-fizycznym medium łączącym ludzką niedoskonałość („Nie: tylko trochę mniej niedoskonali niż każdy”) z doskonałością („Tak, ale na mgnienie ocali ich to, że wystają o głowę ponad tę resztę, to wszystko"). Za szybą telewizyjnego ekranu, dzięki dostępnemu jednym naciśnięciem przycisku pilota osobistemu uczestnictwu w transmisji, oczom spragnionego widza otwierał się ocean odwiecznych ludzkich marzeń o osiągnięciu choćby na moment pełni doskonałości.

W wydaniu Barańczaka koszykówka nie jest i nie ma być biomechaniczną grą doskonale wyszkolonych bezdusznych robotów. Jest grą w pocie czoła uprawianą przez różnorako uzdolnionych, utalentowanych ludzi, jak świat światem zmagających się z przeciwnościami, odwiecznie niedoskonałych, ale uparcie dążących do celu. Ludzi, którzy wiedzą, co to słabość. Łączy ich i czyni drużyną to, iż wystają głowami i uniesionymi w górę rękoma ponad przeciętność, niestrudzenie czegoś próbując. I taką właśnie koszykówkę poetów basketu ocala autor w swoim wierszu.

Jest coś magicznego i mitycznego w tym, kiedy nowożytni herosi, mierzący ponad dwa metry, potężni gracze szybują pod tablicą w napowietrznych paradach, aby na oczach audytorium wypełniającego po brzegi sportową halę umieścić z niezawodną (czytaj: chirurgiczną) precyzją i gracją piłkę w koszu. Podobna magia staje się udziałem czytelnika obserwującego kunszt poety, którego - mistrzowsko zorganizowany w materii, dokładnie tych co trzeba, słów - wiersz oddaje ekspresję i energię przetaczającego się przez halę i ekran żywiołu.

Nie ma już tamtych Celtów, nie ma też słynnej hali o nazwie Boston Garden, w której występowali przed własną publicznością - zastąpionej w połowie lat dziewięćdziesiątych przez nowoczesną TD Garden. Jak echo „oceanicznego ryku nabitej głowami hali”, został nam po tamtym minionym Olimpie wielkiego basketu i jego mitycznych herosach wspaniały wiersz. Spośród milionowej rzeszy kibiców koszykówki na świecie Stanisław Barańczak jest tym, który najpiękniej przemienił ją w poezję. 
